\title{
Modifikasi Limbah Abu Layang menjadi Adsorben untuk Mengurangi Limbah Zat Warna pada Industri Tekstil
}

\author{
Bachrun Sutrisno $^{1}$, Arif Hidayat ${ }^{1}$, dan Zahrul Mufrodi ${ }^{2}$ \\ ${ }^{1}$ Teknik Kimia, Fakultas Teknologi Industri, Universitas Islam Indonesia, Jl. Kaliurang km 14, Sleman, \\ Yogyakarta. \\ arhidayat@fti.uii.ac.id \\ ${ }^{2}$ Teknik Kimia, Fakultas Teknologi Industri, Universitas Ahmad Dahlan Yogyakarta, Jl. Prof. Soepomo \\ Janturan, Umbulharjo, Yogyakarta
}

\begin{abstract}
Abundant supplies of coal make this compound as alternative fuels, especially for the industry. However, using of coal has shortcomings; incomplete combustion of coal produces solid waste that often called the fly ash. Results of mineral analysis showed that fly ash contain metal oxides such as silica (SiO2), alumina $\left(\mathrm{Al}_{2} \mathrm{O}_{3}\right)$ and iron $\left(\mathrm{Fe}_{2} \mathrm{O}_{3}\right)$. The presence of silica and alumina components allows fly ash to be synthesized into materials that have structure similar to zeolite. This material is known as zeolite like materials (ZLM).

This study aims to synthesize ZLM of fly ash as adsorbent material. To determine the successful of synthesis also has been analyzed physicochemical properties of zeolite-like material. Then the results are used as adsorbent of textile dyes.

The results showed that fly ash can be synthesized into zeolite-like material, this is indicated by the increasing of physicochemical properties. The experiment shown that the adsorption ability of fly ash in the reduction of textile dyes after modifiedis better.
\end{abstract}

Keywords : zeolite, textile dyes, fly ash.

\section{Pendahuluan}

Pada saat ini pabrik-pabrik banyak yang menggunakan batu bara sebagai bahan bakarnya. Sehingga jumlah limbah abu layang batubara (fly ash) yang dihasilkan dari proses pembakaran batubara sangat besar, tak terkecuali di Pembangkit Listik Tenaga Uap (PLTU). Limbah abu layang batubara yang relatif besar inidapat menimbulkan dampak pencemaran yang cukup berbahaya. Sehingga perlu dipikirkan alternatif pemecahan permasalahan pencemaran ini.

Hasil análisis kandungan mineral menunjukkan bahwa abu layang mengandung oksida-oksida logam termasuk logam-logam berat dalam jumlah kecil. Oksida utama dari abu layang batubara adalah silika $\left(\mathrm{SiO}_{2}\right)$, alumina $\left(\mathrm{Al}_{2} \mathrm{O}_{3}\right)$ dan besi $\left(\mathrm{Fe}_{2} \mathrm{O}_{3}\right)$. Keberadaan komponen silika dan alumina memungkinkan abu layang untuk dapat disintesis menjadi material yang strukturnya mirip dengan zeolit atau dikenal dengan zeolite like material (ZLM). Struktur zeolit yang berpori merupakan sifat yang dapat dimanfaatkan sebagai material adsorben suatu vahan pencemar yang dikeluarkan dari suatu industri.

Salah satu industri yang cukup potencial dalam mencemari lingkungan adalah industria tekstil dengan limbah cairnya yang mengandung zat warna. Pada industria tekstil, zat warna digunakan dalam proses pewarnaan kain dan benang. Pengolahan limbah zat warna dari industria tekstil perlu dilakukan sebelum dibuang kebadan air, karena kandungan zat warna yang tinggi akan mengganggu transmisi cahaya dan menyebabkan turunnya kadar oksigen terlarut dalam air, $\mathrm{pH}$ menjadi asam serta gangguan terhadap kehidupan air. Penggunaan adsorben pada limbah industri tekstil akan mengurangi kadar zat warna, sehingga limbah cair akan aman untuk dibuang kelingkungan sesuai dengan baku mutu yang ditetapkan oleh pemerintah. Di sisi lain, hal tersebut membantu penyelesaian masalah pembuangan limbah abu layang dari PLTU.

Pada penelitian ini akan dikembangkan bahan adsorben dari abu layang yang merupakan limbah hasil pembakaran batubara di PLTU. Kandungan mineral dan struktur bangun dari abu layang sangat memungkinkan untuk digunakan menjadi bahan adsorben limbah zat warna. Sebelum digunakan sebagai bahan adsorben, abu layang disintesis menjadi zeolitlike material (ZLM) dengan proses dekomposisi. 
Berdasarkan uraian di atas, penelitian ini memiliki tujuan yaitu sintesis ZLM dari abu layang sebagai bahan adsorben limbah zat warna. Pemanfaatan abu layang diharapkan akan dapat menambah nilai ekonomis dari limbah padat industri PLTU. Serta membuat bahan adsorben dari abu layang akan dapat digunakan untuk proses pengurangan limbah zat warna dari industri tekstil.

Abu layang atau fly ash adalah material pozzolanic hasil samping dari pembakaran batubara. Abu layang terbentuk karena adanya mineral-mineral yang tidak mudah terbakar yang terkandung di dalam batubara, seperti Silika (Si), Alumina (Al) dan Besi (Fe). Kandungan mineral dalam abu layang bervariasi tergantung dari jenis batubara yang digunakan.

Karena tingginya kandungan silika dan alumina didalamnya, abu layang dapat dimanfaatkan sebagai sumber silika dan alumina dalam sintesis material zeolit. Struktur zeolit dapat dilihat pada Gambar 1. Berdasar struktur padatan yang berpori dan memiliki rongga-rongga serta stabilitas termal yang besar, material mirip zeolit dapat difungsikan sebagai pengemban logam katalis atau adsorben.<smiles></smiles>

Gambar 1. Komposisi dan struktur Zeolit

Usaha untuk memperbaiki kristalinitas dan efektifitas abu layang telah banyak dilakukan yaitu dengan cara dekomposisi abu layang. Dekomposisi bertujuan menghilangkan senyawa pengotor pada abu layang, sehingga dapat memperbaiki struktur kristal, porositas dan daya adsorpsi terhadap beberapa ion logam.

Metode dekomposisi yang banyak digunakan adalah pencucian dengan cara refluks abu layang menggunakan larutan alkali atau asam. Prinsip dekomposisi tersebut adalah memperkecil kandungan senyawa pengotor yang terikut dalam abu layang. Penghilangan senyawa pengotor akan menaikkan kristanilitas abu layang, dengan demikian akan menaikkan kinerja abu layang sebagai material katalis atau adsorben [1].

Peneliti yang lainnya telah mempelajari sintesis abu layang menjadi ZLM dengan metode dekomposisi dengan larutan alkali yang diikuti dengan reaksi hidrotermal. Hasil penelitian menunjukkan bahwazeolit yang terbentuk adalah zeolit jenis $\mathrm{P}$ [2]. Pada penelitian yang lainnya telah dilaporkan bahwa reaksi hidrotermal terhadap abu layang menggunakan larutan $\mathrm{NaOH}$ pada suhu $100^{\circ} \mathrm{C}$ berhasil memperoleh memperoleh ZLM jenis Na-Pi, Na-A dan hidroksisaudalite [3]. Sintesis ZLM dari abu layang juga telah diteliti, hasil penelitian menunjukkan bahwa ZLM yang terbentuk bervariasi, antara lain NaP1, Analsim, sodalit, tobermorit, zeolit $\mathrm{F}$ danzeolit $\mathrm{A}$. Hal ini terjadi karena pada proses sintesisnya dilakukan variasi terhadap jenis larutan alkali, konsentrasi larutan dan suhu reaksi hidrotermal [4].

Penelitian tentang sintesis abu layang dengan dekomposisi menggunakan larutan $\mathrm{H}_{2} \mathrm{SO}_{4}$ pada berbagai konsentrasi [1]. Hasil penelitian menunjukkan bahwa ZLM yang terbentuk dapat digunakan untuk material adsorben senyawa ammonium dan fosfat dari air buangan. Sintesis sintesis Faujasite dari abu layang batubara telah dilakukan [5]. Pada penelitian ini sintesis Faujasite dari abu layang batubara dilakukan melaluitahapan-tahapan proses refluks, penggerusan, peleburan dan reaksi hidrotermal.

Penelitian menggunakan ZLM untuk mengurangi kadar ion ammonium $\left(\mathrm{NH}_{4}{ }^{+}\right)$dan logam berat dari limbah buangan cair dan limbah industri pelapisan logam[6]. Penelitian yang lainnya tentang pemanfaatan ZLM dari abu layang sebagai penukar kation (cation exchange). ZLM yang disintesis dapat digunakan untuk proses adsorpsi ion Timbal $(\mathrm{Pb})$ dan Seng $(\mathrm{Zn})$ dari limbah cair industri. ZLM yang diperoleh pada penelitian ini adalah Zeolite $\mathrm{P}$ dan hidroksisodalite [7]. Pada penelitian yang lain dihasilkan sintesis ZLM dari abu layang pada beberapa kondisi penelitian yang berbeda, yaitu variasi konsentrasi larutan alkali dan suhu reaksi hidrotermal [8].

Selain untuk mengurangi konsentrasi limbah logam berat dalam limbah cair, ZLM telah dipelajari untuk proses adsorpsi ion fosfat dalam limbah cair [9]. Hasil penelitian menunjukkan bahwa pengurangan konsentrasi ion fosfat akan meningkat dengan bertambahnya massa adsorben ZLM dan pada keadaan $\mathrm{pH}$ yang rendah pengurangan konsentrasi ion fosfat semakin menurun. juga Peneliti lain mempelajari pengurangan ion fosfat dengan adsorben ZLM. Hasil penelitian menunjukkan bahwa adsorpsi ion fosfat paling terjadi pada $\mathrm{pH} 3$-3,5 dengan terbentuk kalsium fosfat pada permukaan adsorben [10]. 
Selain untuk proses adsorpsi pada limbah cair, kemampuan ZLM dari abu layang sebagai adsorben pada adsorpsi gas $\mathrm{SO}_{2}$ dari limbah gas. Hasil penelitian menunjukkan bahwa adsorben ZLM mempunyai kemampuan yang tinggi dalam mengurangi kadar gas $\mathrm{SO}_{2}$ dalam limbah gas sampai $100 \%$ atau zero $\mathrm{SO}_{2}$ emission [11].

Pemanfaatan ZLM untuk adsorbsi zat warna pada limbah cair belum banyak dilakukan. Dari hasil penelusuran pustaka diperoleh data tentang adsorpsi logam berat dan zat warna dari limbah cair. ZLM yang digunakan disintesis dengan metode alkali yang diikuti dengan reaksi hidrotermal. Hasil penelitian menunjukkan bahwa ZLM yang terbentuk adalah zeolit $\mathrm{P}$ yang dapat digunakan untuk melakukan proses adsorpsi logam nikel $(\mathrm{Ni})$ dan tembaga $(\mathrm{Cu})$ serta limbah zat warna [12].

Adsorpsi adalah proses perpindahan massa suatu konstituen atau solut dari campuran fase cair atau gas ke permukaan padatan, sehingga pemisahan konstituen dari campuran tersebut dapat terjadi. Sebagai komponen yang akan dipindahkan atau diadsorp disebut adsorbat, sedangkan komponen yang akan menyerap atau mengadsorp disebut adsorben. Secara garis besar, pada proses adsorpsi ini terjadi perpindahan massa dari fase cair atau gas ke fase padat.

Mekanisme proses adsorpsi zat warna telah dikemukan, adsorpsi yang terjadi pada zat warn adari suatu larutan meliputi tiga tahapan, yaitu: (a) difusi melewati lapisan batas antara cairan dan permukaan luar adsorben, (b) difusi dari permukaan luar adsorben ke dalam pori-pori adsorben, dan (c) adsorpsi ke permukaan padatan. Tahapan (c) diasumsikan berlangsung dengan cepat, sehingga yang mengontrol proses adsorpsi adalah tahapan (a) dan (b). Untuk meningkatkan kemampuan adsorpsi, maka tahanan yang disebabkan oleh tahapan (a) dan (b) diperkecil, diantaranya dengan mempercepat pengadukan, menaikkan suhu atau menurunkan $\mathrm{pH}[13]$.

Penelitian tentang proses adsorpsi zat warna dari limbah cair industri tekstil telah dilakukan oleh beberapa peneliti dengan berbagai jenis adsorben diantaranya: zeolit, karbon aktif, dan lempung (clay). Adsorpsi zat warna jenis Congo Red dengan menggunakan beberapa jenis karbin aktif yang dibuat dari serbuk bambu, tempurung kelapa, kulit kacang tanah, sekam padi serta jerami padi. Hasil penelitian menunjukkan bahwa prosentase pengurangan konsentrasi Congo Red akan meningkat dengan semakin kecilnya ukuran partikel karbon aktif dan semakin rendahnya $\mathrm{pH}$ [14]. Peniliti lain telah mempelajari tentang adsorpsi zat warna jenis malachite green dengan menggunakan adsorben karbon aktif komersial dan karbon aktif dari kulit kacang tanah [15]. Penelitian dilakukan dengan melakukan variasi terhadap jumlah adsorben yang digunakan, konsentrasi malachite green dan waktu kontak. Beberapa peneliti lain juga telah mempelajari proses adsorpsi dengan adsorben karbon aktif pada berbagai jenis zat warna, di antaranya: Acid Blue 40 and Acid Yellow 17 [16], methylene blue [17] dan Reactive Black 5 [18].

Disamping karbon aktif, penelitian tentang penggunaan jenis adsorben lain untuk adsorpsi zat warna juga telah dilakukan. Ada peneliti yang menggunakan asam humat yang diimobilisasi dalam alumina terpilar untuk proses adsorpsi zat warna jenis methylene blue, crystal violet dan rhodamine B[19]. Kemampuan adsorpsi zeolit alam yang dimodifikasi untuk mengurangi konsentrasi zat warna dasar (basic dye) dan reaktif. Zeolit dimodifikasi dengan larutan cetyltrimethylammonium bromide (CTAB) and hexadecyltrimethylammonium bromide (HDTMA) untuk meningkatkan aktifitas dan selektifitas material adsorben[20].

Jenis mineral alam selain zeolit yang dapat digunakan untuk proses adsorpsi adalah lempung. Lempung yang dimodifikasi untuk mengurangi konsentrasi zat warna asam jenis Supranol Yellow 4GL[21]. Peneliti lain, menggunakan lempung sebagai adsorben untuk pengurangan konsentrasi zat warna jenis malachite green. Lempung yang digunakan sebagai adsorben dipreparasi dengan metode pengeringan menggunakan oven[22].

Dari uraian diatas, maka dalam penelitian ini akan dilakukan sintesis ZLM dari abu layang untuk keperluan adsorpsi beberapa zat warna seperti Alizarin S, Congo Red dan Methylen Red. Sintesis ZLM dilakukan dengan cara dekomposisi abu layang yang dilanjutkan dengan reaksi hidrotermal.

\section{Metodologi}

Bahan yang digunakan dalam penelitian adalah: abu layang dari PLTU Suralaya, zat warna Naphtol dan Indigosol, larutan $\mathrm{H}_{2} \mathrm{SO}_{4}$ pekat (95-97\%) dan larutan $\mathrm{HNO}_{3}$ pekat (65\%) untuk dekomposisi abu layang, $\mathrm{NaOH}$ untuk sintesis ZLM dari abu layang, $\mathrm{Al}_{2} \mathrm{O}_{3}$ untuk pembibitan struktur zeolit.

Sedangkan alat yang dipakai adalah: lumpang porselen untuk menggerus abu layang, ayakan 200 mesh untuk memperoleh abu layang dengan ukuran yang homogen, alat-alat gelas untuk preparasi dan 
dekomposisi abu layang, reaktor oksidasi dan kalsinasi untuk reaksi hidrotermal, oven untuk keperluan pemeraman (aging), instrumen untuk karakterisasi ZLM, dan alat uji adsorpsi zat warna.

Larutan zat warna, yaitu: Methylene Blue dan Rhodamine B dengan konsentrasi tertentu dimasukkan ke dalam labu leher tiga yang dilengkapi dengan pengaduk. Adsorben ZLM sejumlah tertentu dimasukkan kedalam larutan zat warna dan pengaduk mulai dihidupkan dengan kecepatan tertentu. Pada setiap selang waktu tertentu, sampel diambil dengan pipet ukur untuk diukur absorbansinya dengan spektrofotometer. Untuk mendapatkan parameter keseimbangan, percobaan dilakukan variasi, yaitu: waktu adsorbsi, perbandingan massa adsorben dan volume larutan, kecepatan pengadukan saat adsorbsi.

\section{Hasil dan Pembahasan}

Adsorban yang digunakan adalah fly ash yangsudah termodifikasi. Luas permukaan bertambah dari semula setelah mengalami modifikasi seperti pada Tabel 1. berikut ini.

Tabel 1. Data analisis luas permukaan spesifik

\begin{tabular}{lcc}
\hline Parameter & Abu layang & Abu layang aktivasi \\
\hline Luas permukaan spesifik $\left(\mathrm{m}^{2} / \mathrm{g}\right)$ & 4,975 & 45,716 \\
Volume Pori $\left(\mathrm{cm}^{3} / \mathrm{g}\right)$ & $0,01374.10^{-3}$ & $0,1572.10^{-3}$ \\
Reratajejaripori $(\AA)$ & 13,6605 & 11,998 \\
\hline
\end{tabular}

Dari Tabel 1 dapat dilihat kenaikan luas permukaan spesifik terjadi oleh proses aktivasi mineral abu layang dari sebesar 4,975 m²/g menjadi $45,716 \mathrm{~m}^{2} / \mathrm{g}$. Kenaikan luas permukaan spesifik ini disertai dengan penurunan rerata jejari pori dari $13,6605 \AA$ menjadi $11,998 \AA$. Hal ini menunjukkan bahwa aktivasi menyebabkan kenaikan distribusi ukuran pori mineral pada range mikropori sebagai akibat dari defisiensi mineral pengotor. Untuk pengaruh jenis Adsorben disajikan pada pembahasan berikut.

\section{Pengaruh Jenis Adsorben pada Kemampuan Adsorpsi Rhodamine-B}

Untuk mengetahui kemampuan adsorben abu layang termodifikasi dalam adsorpsi zat warna jenis Rhodamine-B dilakukan pengamatan terhadap abu layang yang dimodifikasi perendaman dengan larutan $\mathrm{HCl}$ (FA-HCl) dan perendaman dengan larutan $\mathrm{NaOH}(\mathrm{FA}-\mathrm{NaOH})$. Modifikasi dilakukan untuk menghilangkan bahan-bahan organik pengotor yang menghambat pori-pori abu layang yang dapat mengurangi daya serap abu layang. Seperti terlihat pada Gambar 2.

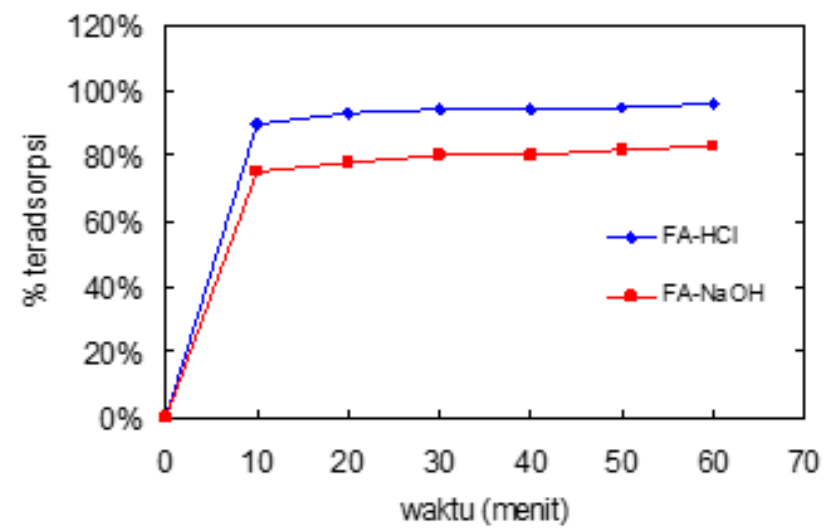

Gambar 2. Pengaruh jenis adsorben terhadap kemampuan adsorpsi Rhodamine-B (suhu atmosferik, kecepatan putaran $20 \mathrm{rpm}, \mathrm{m} / \mathrm{V}=1 / 100$ )

Dari Gambar 2 diketahui bahwa abu layang yang dimodifikasi dengan perlakuan perendaman menggunakan larutan $\mathrm{NaOH}$ memberikan prosentase penyerapan yang lebih besar dibandingkan dengan abu layang yang dimodifikasi dengan perlakuan perendaman menggunakan larutan $\mathrm{HCl}$. Hasil penelitian menunjukkan pada 10 menit pertama terjadi penurunan konsentrasi zat warna secara signifikan pada kedua sampel. Pada 10 menit berikutnya jumlah Methylene Blue yang teradsorpsi cenderung konstan sampai tercapai waktu 60 meningkat. Hal ini menunjukkan adsorben mampu untuk mengurangi konsentrasi zat warna sampai $80-90 \%$. 


\section{Pengaruh perbandingan massa adsorben dengan volume larutan kemampuan adsorpsi Rhodamine-B}

Selanjutnya untuk mengetahui pengaruh perbandingan massa adsorben dengan volume larutan $(\mathrm{m} / \mathrm{V})$ terhadap adsorpsi zat warna Rhodamine-B dilakukan pengamatan terhadap sampel abu layang yang dikenai perlakuan basa $(\mathrm{FA}-\mathrm{NaOH})$ pada adsorpsi dengan memvariasikan perbandingan massa adsorben dengan volume larutan. Sampel yang diamati adalah FA-NaOH dengan m/V=1/100 dan 1/200. Hasil penelitian disajikan dalam Gambar 3.

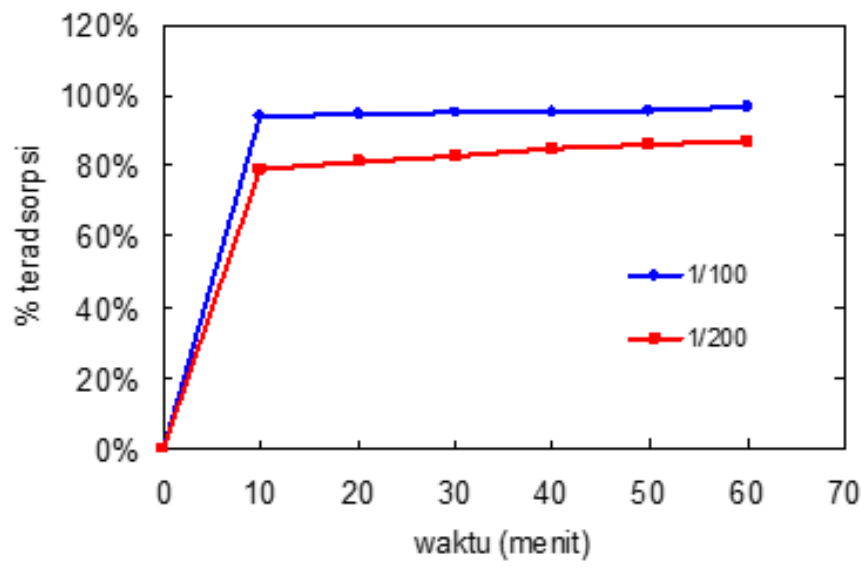

Gambar 3. Pengaruh perbandingan massa adsorben dengan volume larutan terhadap kemampuan adsorpsi Rhodamine-B (suhu atmosferik, sampel FA-NaOH, kecepatan putaran 20 rpm)

Dari Gambar 3 terlihat pengaruh perbandingan massa adsorben dengan volume larutan pada kemampuan adsorpsi sampel FA-NaOH. Pada perbandingan massa adsorben dengan volume larutan yang tinggi atau jumlah adsorben yang lebih banyak menunjukkan kemampuan adsorpsi Rhodamine-B yang relatif besar dibandingkan sampel dengan perbandingan massa adsorben dengan volume larutan yang rendah. Hal ini dikarenakan tersedianya luas permukaan yang lebih besar pada sampel dengan perbandingan massa adsorben dengan volume larutan yang tinggi sehingga lebih banyak Rhodamine-B yang teradsorpsi pada permukaan.

\section{Pengaruh suhu terhadap kemampuan adsorpsi Rhodamine-B}

Untuk mengetahui pengaruh kemampuan adsorben abu layang termodifikasi dalam adsorpsi zat warna jenis Rhodamine-B terhadap suhu, dilakukan pengamatan sampel yang dikenai perlakuan pemanasan pada saat adsorpsi. Suhu pemanasan yang diamati adalah suhu atmosferik $\left(32^{\circ} \mathrm{C}\right)$ dan $45^{\circ} \mathrm{C}$. Hasil penelitian dapat dilihat dalam Gambar 4.

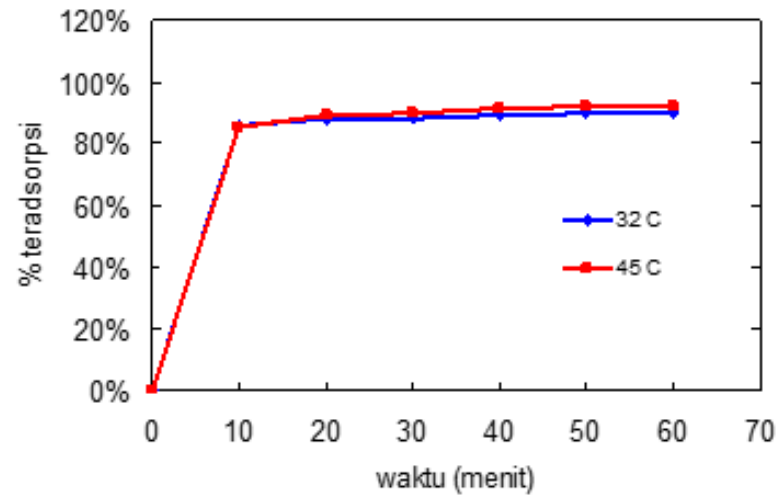

Gambar 4. Pengaruh suhu terhadap kemampuan adsorpsi Rhodamine-B (sampel FA-NaOH, kecepatan putaran $20 \mathrm{rpm}, \mathrm{m} / \mathrm{V}=1 / 100$ )

Dari Gambar 4 terlihat bahwa suhu tidak terlalu berpengaruh terhadap kemampuan adsorpsi Methylene Blue oleh sampel FA-NaOH. Pada suhu adsorpsi yang lebih rendah tidak menunjukkan perbedaan 
yang signifikan dibandingkan dengan suhu suhu adsorpsi yang lebih tinggi. Terutama di dua puluh menit pertama hasilnya sama.

\section{Pengaruh kecepatan putaran pengaduk terhadap kemampuan adsorpsi Rhodamine-B}

Pada penelitian ini dilakukan pengamatan terhadap pengaruh adsorpsi zat warna Rhodamine-B dengan sampel FA-NaOH pada kecepatan putaran $40 \mathrm{rpm}$ dan $80 \mathrm{rpm}$. Hasil pengamatan disajikan dalam Gambar 5.

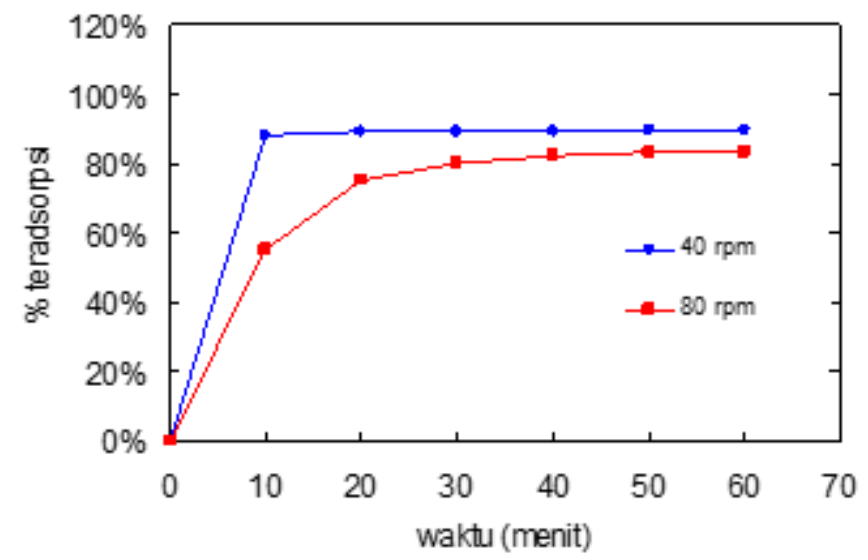

Gambar 5. Pengaruh kecepatan putaran pengaduk terhadap kemampuan adsorpsi Rhodamine-B (suhu atmosferik, sampel FA- $\mathrm{NaOH}, \mathrm{m} / \mathrm{V}=1 / 100$ )

Dari Gambar 5 terlihat pengaruh kecepatan putaran pengaduk pada kemampuan adsorpsi sampel FA-NaOH. Pada kecepatan putaran pengaduk yang tinggi $(80 \mathrm{rpm})$ Methylene Blue yang teradsorpsi pada permukaan sampel lebih rendah dibandingkan dengan sampel yang menggunakan putaran pengaduk yang lebih lambat (40 rpm).

\section{Pengaruh konsentrasi awalterhadap kemampuan adsorpsi Rhodamine-B}

Selain itu pengamatan adsorpsi Rhodamine-B oleh adsorben FA-NaOH juga dilakukan pada konsentrasi awal zat warna Rhodamine-B yang berbeda-beda, yaitu $10 \mathrm{ppm}$ dan $20 \mathrm{ppm}$. Pengaruh konsentrasi awal rhodamine B terhadap persen penyerapan dapat dilihat pada Gambar 6.

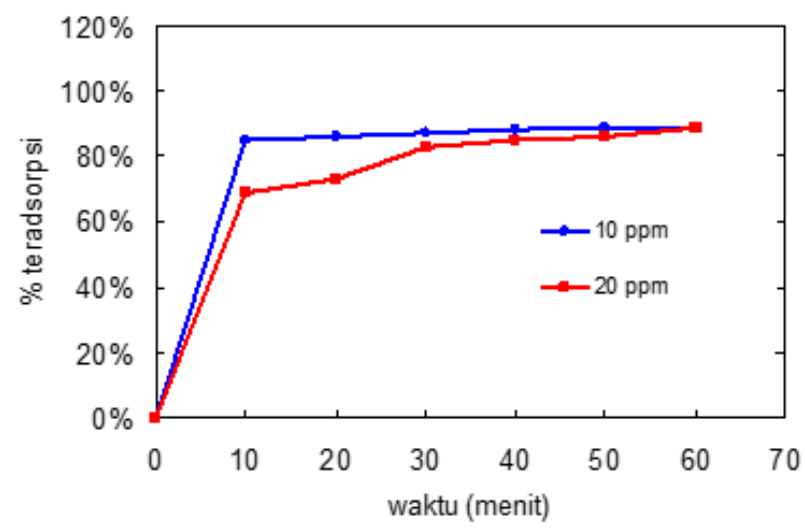

Gambar 6. Pengaruh konsentrasi awal terhadap kemampuan adsorpsi Rhodamine-B (suhu atmosferik, sampel FA- $\mathrm{NaOH}, \mathrm{m} / \mathrm{V}=1 / 100$ )

Pada Gambar 6 diketahui semakin kecil konsentrasi Rhodamine-B maka nilai persen penyerapan semakin besar. Hal ini dikarenakan semakin kecil konsentrasi rhodamine B maka kompetisi antar molekul Rhodamine-B yang terjadi semakin kecil, akibatnya laju diffusipun menjadi relatif cepat. 


\section{Adsorpsi Methylene Blue}

Kemampuan adsorben abu layang termodifikasi dalam adsorpsi zat warna jenis Methylene Blue dapat diketahui dari pengamatan terhadap tiga jenis abu layang yang dikenai perlakuan berbeda, yaitu abu layang mentah dengan perlakuan pemanasan (FA-mentah), abu layang dengan perlakuan perendaman dengan larutan $\mathrm{HCl}(\mathrm{FA}-\mathrm{HCl})$ dan abu layang dengan perlakuan perendaman dengan larutan $\mathrm{NaOH}(\mathrm{FA}-\mathrm{NaOH})$. Pengamatan dilakukan pada suhu atmosferik dengan kecepatan pengaduk $20 \mathrm{rpm}$ dan perbandingan massa adsorben dengan volume larutan Methylene Blue = 1 / 50. Hasil penelitian disajikan dalam Gambar 7 .

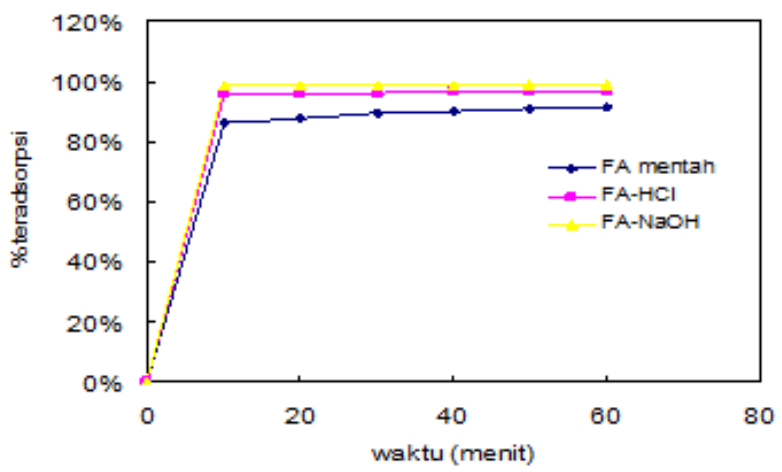

Gambar 7. Pengaruh jenis adsorben terhadap kemampuan adsorpsi Methylene Blue (suhu atmosferik, kecepatan putaran $20 \mathrm{rpm}, \mathrm{m} / \mathrm{V}=1 / 50$ )

Gambar 7 memberi informasi tentang hasil penelitian menunjukkan pada 10 menit pertama terjadi penurunan konsentrasi zat warna secara signifikan pada ketiga sampel. Pada 10 menit berikutnya jumlah Methylene Blue yang teradsorpsi cenderung konstan sampai tercapai waktu 60 meningkat. Hal ini menunjukkan adsorben mampu untuk mengurangi konsentrasi zat warna sampai 99\%. Dari Gambar 2 juga terlihat sampel abu layang yang mengalami perlakuan asam dan basa menunjukkan kemampuan adsorpsi dibandingkan dengan abu layang tanpa perlakuan.

Selanjutnya untuk mengetahui pengaruh putaran pengaduk terhadap adsorpsi zat warna Methylene Blue dilakukan pengamatan terhadap sampel abu layang yang dikenai perlakuan basa (FA-NaOH) pada adsorpsi dengan memvariasikan kecepatan putaran pengaduk. Hasil penelitian disajikan dalam Gambar 8 .

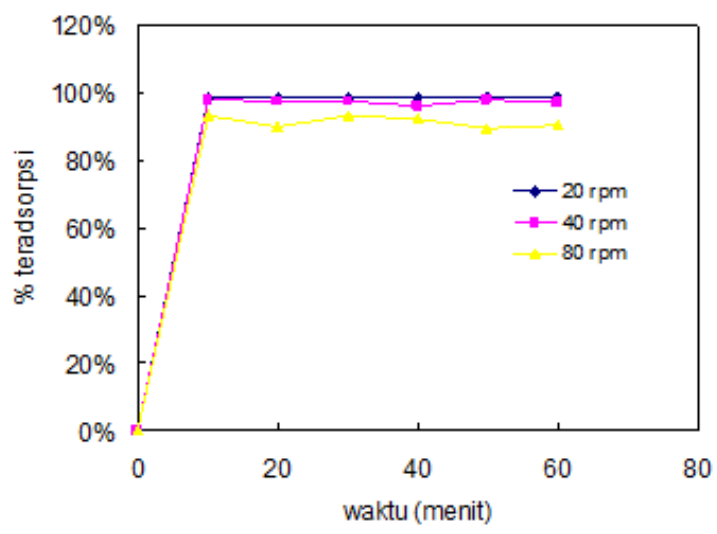

Gambar 8. Pengaruh kecepatan putaran pengaduk terhadap kemampuan adsorpsi Methylene Blue (suhu atmosferik, sampel FA-NaOH, $\mathrm{m} / \mathrm{V}=1 / 50$ )

Dari Gambar 8 terlihat pengaruh kecepatan putaran pengaduk pada kemampuan adsorpsi sampel FA-NaOH. Pada kecepatan putaran pengaduk yang tinggi $(80 \mathrm{rpm})$ Methylene Blue yang teradsorpsi pada permukaan sampel lebih rendah dibandingkan dengan sampel yang menggunakan putaran pengaduk yang lebih lambat. Sedangkan pada kecepatan pengaduk 20 dan $40 \mathrm{rpm}$ tidak terlihat perbedaan yang signifikan dalam kemampuan adsorpsi Methylene Blue.

Pada penelitian ini juga dilakukan pengamatan terhadap perbandingan massa adsorben dengan volume larutan $(\mathrm{m} / \mathrm{V})$ terhadap adsorpsi zat warna Methylene Blue. Sampel yang diamati adalah FA-NaOH dengan $\mathrm{m} / \mathrm{V}=1 / 50$ dan $1 / 100$. Hasil penelitian disajikan dalam Gambar 9. 


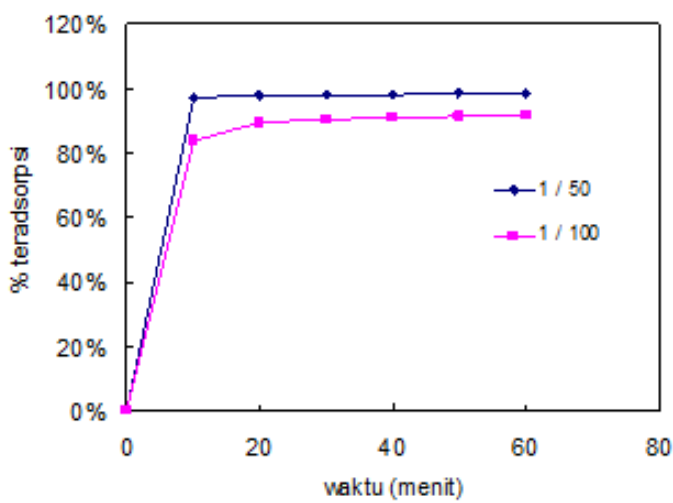

Gambar 9. Pengaruh perbandingan massa adsorben dengan volume larutan terhadap kemampuan adsorpsi Methylene Blue (suhu atmosferik, sampel FA- $\mathrm{NaOH}$, kecepatan putaran $20 \mathrm{rpm}$ )

Gambar 9 memberikan gambaran tentang pengaruh perbandingan massa adsorben dengan volume larutan pada kemampuan adsorpsi sampel FA-NaOH. Pada perbandingan massa adsorben dengan volume larutan yang tinggi atau jumlah adsorben yang lebih banyak menunjukkan kemampuan adsorpsi Methylene Blue yang relatif besar dibandingkan sampel dengan perbandingan massa adsorben dengan volume larutan yang rendah. Hal ini dikarenakan tersedianya luas permukaan yang lebih besar pada sampel dengan perbandingan massa adsorben dengan volume larutan yang tinggi sehingga lebih banyak Methylene Blue yang teradsorpsi pada permukaan.

Untuk mengetahui pengaruh kemampuan adsorben abu layang termodifikasi dalam adsorpsi zat warna jenis Methylene Blue terhadap suhu, dilakukan pengamatan sampel yang dikenai perlakuan pemanasan pada saat adsorpsi. Suhu pemanasan yang diamati adalah suhu atmosferik $\left(32^{\circ} \mathrm{C}\right)$ dam $45^{\circ} \mathrm{C}$. Hasil penelitian disajikan dalam Gambar 10.

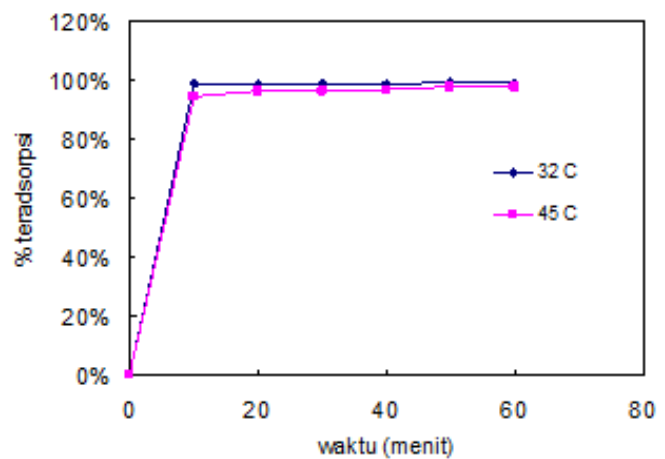

Gambar 10. Pengaruh suhu terhadap kemampuan adsorpsi Methylene Blue (sampel FA-NaOH, kecepatan putaran $20 \mathrm{rpm}, \mathrm{m} / \mathrm{V}=1 / 50$ )

Dari Gambar 10 terlihat bahwa suhu tidak terlalu berpengaruh terhadap kemampuan adsorpsi Methylene Blue oleh sampel FA-NaOH. Pada suhu adsorpsi yang lebih rendah tidak menunjukkan perbedaan yang signifikan dibandingkan dengan suhu suhu adsorpsi yang lebih tinggi.

\section{Kesimpulan}

Secara keseluruhan dari hasil sintesis abu layang menjadi material mirip zeolit telah berhasil dilakukan, hal ini terlihat dengan adanya peningkatan sifat fisikokimiawi mineral abu layang Hasil karakteristik abu layang pada uji coba terlihat mempunyai kemampuan adsorpsi dalam mengurangi konsentrasi zat warna tekstil. Karakteristik abu layang yang digunakan untuk penjerapan zat warna rhodamine-B dan methylen blue dapat dilakukan dengan baik. Efektivitas waktu yang digunakan berkisar pada menit ke 10 setelah adsorpsi dilakukan. 


\section{Daftar Pustaka}

[1] Zhang, B., Wu, D, Wang, C., He, S., Zhang, Z., and Kong, H., 2007, Simultaneous removal of ammonium and phosphate by zeolite synthesized from coal fly ash as influenced by acid treatment, Journal of Environmental Sciences, Volume 19, Issue 5, Pages 540-545.

[2] Murayama, N., Yamamoto, H., and Shibata, J., Mechanism of zeolite synthesis from coal fly ash by alkali hydrothermal reaction, International Journal of Mineral Processing, Volume 64, Issue 1, February 2002, Pages 1-17.

[3] Shigemoto, N. Hayashi, H. and Miyaura, K. Selective formation of Na-X zeolite from coal fly ash by fusion with sodium hydroxide prior to hydrothermal reaction, Journal of Materials Science, Volume 28, Number 17, pages 4781-4786.

[4] Querol, X., Umaña, J. C., Plana, F., Alastuey, A., Lopez-Soler, A., Medinaceli, A., Valero, Domingo, A., M. J., and Garcia-Rojo, E., 2001, Synthesis of zeolites from fly ash at pilot plant scale. Examples of potential applications, Fuel, Volume 80, Issue 6, pages 857-865.

[5] Sutarno, Arryanto, Y. danBudhyantoro, A., 2004, SintesisFaujasitedari Abu Layang Batubara : PengaruhRefluksdanPenggerusan Abu Layang Batubara terhadapKristalinitasFaujasite, JurnalMatematikadanSains Vol. 9 No. 3, hal 285-290.

[6] Amrhein, C. H., Haghnia, G.H., Kim, T.S., Mosher, P.A., Gagajena, R.C., Amanios, T., de la Torre, L., 1996, Synthesis and properties of zeolites from coal fly ash, Environ. Sci. Technol. 30, 735- 742.

[7] Berkgaut, V., Singer, A., 1995, Cation exchange properties of hydrothermally treated coal fly ash, Environ. Sci. Technol. 29 (7), 1748-1753.

[8] Lin, C.F., His, H.C., 1995, Resource recovery of waste fly ash: Synthesis of zeolite-like materials, Environ. Sci. Technol. 29 (4), 1109- 1117.

[9] [9] Onyango, M. S., Kuchar, D., Kubota,M., and Matsuda, H., 2007, Adsorptive Removal of Phosphate Ions from Aqueous Solution Using Synthetic Zeolite, Ind. Eng. Chem. Res., 46, 894-900.

[10] [10] Chen, J., Kong, H., Wu, D., Hu, Z., Wang, Z., and Wang, Y., 2006, Removal of phosphate from aqueous solution by zeolite synthesized from fly ash, Journal of Colloid and Interface Science, 300, 491-497.

[11] Srinivasan, A., Grutzech, M.W., 1999, The Adsorption of SO2 by zeolites synthesized from fly ash, Environ. Sci. Technol. 33, 1464- 1469.

[12] Wang, S., Soudi, M., Li, L., and Zhu, Z. H., 2006, Coal ash conversion into effective adsorbents for removal of heavy metals and dyes from wastewater, Journal of Hazardous Materials B, 133, 243-251.

[13] Dogan, M., andAlkan, M., 2003, Adsorption kinetics of methyl violet onto perlite, Chemosphere, 50, $517-528$

[14] Kannan, N. andMeenakshisundaram, M., 2002, Adsorption of Congo Red on Various Activated Carbons. A Comparative Study. Water, Air, and Soil Pollution 138: 289-305.

[15] Malik, R., Ramteke D. S., and, Wate S.R., 2007, Adsorption of malachite green on groundnut shell waste based powdered activated carbon. Waste Management, 27, 1129-1138.

[16] Ozacar,M., and Sengil, I. A., 2002, Adsorption of Acid Dyes from Aqueous Solutions by CalcinedAlunite and Granular Activated Carbon. Adsorption 8: 301-308.

[17] Hameed, B.H., Ahmad, A.L., and Latiff, K.N.A., 2007, Adsorption of basic dye (methylene blue) onto activated carbon prepared from rattan sawdust. Dyes and Pigments, 75, 143-149.

[18] Eren Z., andAcar F. N.., 2006, Adsorption of Reactive Black 5 from an aqueous solution: equilibrium and kinetic studies, Desalination, 194, 1-10. 
ISSN : 2355-8776

[19] Vinod V. P. and Anirudhan T. S., 2003, Adsorption Behaviour Of Basic Dyes On The Humic Acid Immobilized, Pillared Clay Water, Air, and Soil Pollution, 150, 193-217.

[20] Karadag, D., Akgul, E., Tok, S., Erturk, F., Kaya, M.A., and Turan, M., 2007, Basic and Reactive Dye Removal Using Natural and Modified Zeolites, J. Chem. Eng. Data, 52, 2436-2441.

[21] Bouberka Z., Kacha, S., Kameche, M., Elmaleh, S., and Derriche, Z., 2005, Sorption study of an acid dye from an aqueous solutions using modified clays, Journal of Hazardous Materials B, 119, 117-124.

[22] Tahir, S.S., and Rauf, N., 2006, Removal of a cationic dye from aqueous solutions by adsorption onto bentonite clay, Chemosphere, 63, 1842-1848. 